\title{
Students' Perceptions on Professional Competence of Lecturers at the Department of Arabic Education, Faculty of Islamic Education and Teacher Training, State Institute for Islamic Studies IB Padang
}

\author{
Rehani \\ Department of Arabic, Faculty of Education and Teacher Training, States Institute for Islamic Studies IB Padang \\ E-mail: rehanipdg@yahoo.com \\ DOI: http://dx.doi.org/10.15548/jt.v22i1.110
}

\begin{abstract}
This research examines students' perception on professional competence of Arabic education department lecturers. It seeks to answer questions whether or not educational background, level of education, age, and gender correlate with lecturers' professional competent. In this study, students are asked to answer questions on their lecturers' 1) mastery of subject matters, 2) pedagogical knowledge, 3) attitudes, 4) discipline, 5) clarity on the assessment procedure, 6) the use of teaching media and students' learning achievement. The findings of the study suggest that over $50 \%$ of students perceive their lecturers (those who teach in department of Arabic Education) are qualified enough to carry out their professional responsibilities. The research also uncovers that lecturers' background education, such as between those who graduated from local and overseas universities, does not show any significant difference in their ways of classroom practices. However, the research found that level of education indeed influences lecturer's ways of teaching, especially on the aspects that become the focus of this research. In addition, age does not show much different but in some instances, senior lecturers are more capable at pedagogical content knowledge, assessment, and better of in term of the attitude. Finally, this research also found that gender difference does make difference. Female lecturers, for example are found to be better in all aspects measured for this study.
\end{abstract}

Key Words: Student, Perception, Professional Competence, Lecturer

\section{INTRODUCTION}

Lectures are an important component in educational settings, including in universities. This is because lecturers shape the direction of a university and guarantee qualified graduates. If lecturers are highly qualified, they will be able to engage well in classroom management and instruction. The same is true that if lecturers are incompetent, the graduates will turn to be academic dissatisfied. This shows important role that teachers should take part in producing qualified graduates. For this reason, highly qualified lecturers who are able to produce highly competitive students are gravely in need. The availability of competent lecturers, an educational institution will be able to carry its responsibility to produce qualified graduates. In addition, the presence of competent teachers will improve the quality of an institution, Kayani (2011) mentions that dynamic teaching is possible without a dynamic teacher. So an effective teacher is known through his qualitative teaching. A teacher's function is not mere promotion of literacy by imparting a certain amount of knowledge to pupils .A teacher is the ideal and a model to be followed by the students.

The Act 14, 2005 states that lecturers are those who are professional in their jobs. The Act also mandates lecturers to transform, develop, disseminate knowledge, technology and arts, research, and to engage in community service. For that reason, lecturers bear significant responsibility to transform and educate community as suggested in the Act 14, chapter 5.

As lecturers are important in an educational institution, they should engage in self professional development, as an attempt to improve the quality of the institution. Lecturers therefore should acquire formal academic degree, teaching competence, certification of 
professionalism; physical well being and they also acquire the ability to meet the objective of national education.

Refering to the act 14, 2005, department of Arabic education has met the government regulation. Two lecturers have hold profership, Prof. Dr. H. Masnal Jazuli, M.A dan Prof. Dr. H. Armen Mukhtar; two of them hold doctorate degree Dr. Hj. Hafni Bustami, M.Ag dan Dr. Rehani, M.Ag and 9 of them hold maste5r degree Drs Lokot Nasution M.Ag, Drs Zainul Arifin M.Ag, Drs H.M. Jarir, NA. HD, M.Ag, Dra Husnia Ja'far M.A, Dra Sulha, M.A, Dra Ruwaida, M.Ag, Hanomi, M.A, Neli Putri, M.Ag, and Rahmawati M.Ag. Besides, all of these lecturers have been certified to teach at university.

Besides their academic qualification, lecturers should also be competent, since competent teachers will guarantee the improvement of education. For this very reason, this research examines eight teachers' competence: acquiring subject matter knowledge; pedagogical content knowledge; methods of instruction; discipline; personality and attitude; methods of assessment; the use of learning instructional methods; and improvement of students' understanding.

\section{The Notion of Perception Revisited}

Perception derives from the Greek word perception, in which the root word is percipere, meaning receive or take. In its narrow sense, perception is the someone's ways of seing something, while in the broader sense, the word means outlooks and understanding of something, which is how someone sees something Sobur, 2003:445)

Shaleh \& Wahab (2003) define perception is the process of combining information generated through sense to be developed in such a way that leads to one's awareness about themselves and also surrounding. Others also suggest that perception is the process of differentiating, grouping, and focusing one's attention on certain objects. In the process of grouping and differentiating, the process should be interpreted based on one's experience about his/her events and objects (Shaleh and Wahab, 2005: 88-89).

Kotler as cited by Rangkuti defines as "a process, in which an individual chooses, formulates and interprets input to depict a certain phenomenon" (Rangkuti, 2006:35). Other scholar, Mar'at states that perception is a process of observation through cognitive ability; includes something that need interpretation (Mar'at, 1999:11)

In short, perception can be viewed as ways in which someone gets access into information or captures some information. These perceptions shape people's ways of thinking, define what important and then they will learn how people think and decide the keyword for success (Sapuri, 2009:294).

\section{Lecturers' Performance}

Performance is defined as the degree of one's working achievement. This means that performance is the ability to work as shown by someone to achieve learning goals. This term is commonly used in the field of Management, which is viewed as one's success in carrying out their tasks. Sedarmayanti (1994) states that:

Performance is defined as working quality, carrying tasks, working achievement, and the performance of work". Based on the above definition, performance can be viewed as one's ability to carry out certain tasks successfully (Sedarmayanti, 1994: 53).

Epistemologically as defined in dictionary of education and cited by Nurdin, (1999:12), Profession is an occupation usually involving relatively long and specialized preparation on the level higher education and governed by its own code of ethic; profession is one who has acquired skill and conforms to ethical standard of the profession in which the practice to skill.

While Saleh (2003) mentions that in general sense, profession is a kind of job that needs skill and competence to enable something carry out their task effectively (Saleh, 2003; 268). In addition, professional is one's expertise in carrying out their tasks within their profession, and thus examining lecturers' 
professionalism and performance is the effort to examine lecturers' ways of teaching, in which they acquire subject matter knowledge and also pedagogical content knowledge.

\section{The need for students' perception on their lecturers' performance and professionalism}

Students are object and at the same time the subject of education. These students could not be considered as the knowledge receiver alone, refereeing to the term given by Paulo Freire 'Banking System' of education; students are intellectual human beings, in which they are able to share ideas and also they are able to think creatively and independently.

This study attempts to explore students' perception on their teachers' performance. However, the findings will not be used as a way to denigrate lecturers rather the data could be used as a source of reference for professional improvement. This is relevant with McNamara, and O'Hara (2009) comment that to improve lecturers' professionalism, one should:

1. reflect on and for their action;

2. engage in peer collaboration;

3. ask for feedback on their parctices;

4. access information through reviewing literature;

5. comunicate and browse for information through internet;

6. conduct action research;

7. consult experts on their field of interests;

8. participate in workshops to enhance professioanlism;

9. pursue further education to improve professional competence.

The first effort can be conducted through exploring students' perception on their lecturers' professionalism, and thus it indicates that it is important to explore students' perception as the first step to improve teachers' performance. At the mean time, one of the programs that have been implemented is to assess lectures' performance. This assessment is important to provide insights whether teachers' competence needs to be improved. Comprehensive assessment is needed to examine lecturers' competence; the evaluations include self-evaluation; peer-assessment; students' assessment; lecture's notes and reports and assessment from the head of department.

\section{METHOD}

This is a developmental research, in which students' perception on the professionalism of their lecturers. It seeks to identify how students in the department of Arabic education perceive the professionalism of lecturers teaching at the department. It is expected that the findings of this study will be used as important reference for recruitment of prospective lecturers in the future, and in turns they are able to produce qualified graduates. In gaining the data, the researchers used quantitative research methodology, in which percentage of students' responses (those who enrolled in academic year of 2013-2014) were used as the basis for analysis of lecturers' professionalism and competence. The responses were recorded through questionnaires.

The objects of the study were thirteen lecturers at department of Arabic education, Faculty of Education and Teacher Training, State Institute for Islamic Studies Imam Bonjol in the academic years of 2013-2014. The objects of the study were divided into four groups, base on (a) lecturers' educational backgrounds-those graduated from middle eastern countries and those who did not, (b) lecturers' educational level - master's and doctorate degree, (c) gender-male and female lecturer, and base on (d) age-junior or senior lecturers.

The population of and the sample of the study were the fourth semester students enrolled in the academic years of 2013/2014. The sample was taken through purposive sampling, in which the samples were purposively recruited from those who have the ability to provide sufficient response about their lecturers, since they have been with those lecturers in the past three semesters.

The data were collected through distributing questionnaires to students. The data gained through questionnaires will be analyzed through descriptive statistics. The descriptive statistics refer to the attempt to describe the 
findings through tables, graphs and also charts, without the attempt to generalize the findings. follows:

The steps in data analysis were as

a. Editing, in which the data was reexamined to identify the most relevant data.

b. Coding is the classification of participants' responses and group them based on their common themes.

c. Tally means the process of classification of the participants' responses before they are lodged into the diagram.

$d$. Counting the frequency of the occurrence and percentage of the data. Having been lodged into diagram, the frequency was counted using the following formula.

Note:

$$
P=\frac{F}{N} \times 100
$$

$\mathrm{P}:$ Percentage

$\mathrm{F}$ : frequency

$\mathrm{N}$ : Number of respondents

e. Tabulation. Having classified respondents' responses, the researchers tabulate them into diagram to display the responses.

f. Data Interpretation is the process of interpreting the data obtained from questionnaires.

g. Conclusion is determining the criteria and terms generated from respondents' responses through the following criteria:

$100 \%=\mathrm{All}$

$76-90 \%=$ Common

$51-75=$ Mostly

$50 \%=$ Half

$26-49 \%=$ Small portion

$1-25 \%=$ A few

$0 \%=$ Nothing

\section{FINDINGS}

Eight aspects were examined in the research, mastery of the subject matter; pedagogical content knowledge; discipline, attitude and appearance; instructional methods; assessment procedures, and instructional media, boosting students' comprehension. The perceptions given by respondent were made through considering lecturers' educational background, level of education, gender, and age.

\section{Lecturers' professionalism based on educational background}

Out of 13 lecturers, 2 graduated from overseas universities, while the other 11 graduated from some universities in Indonesia. The objects of the study were represented by A1, A2, A3, A4, A5, B1, B2, B3, B4, B5, B6, $\mathrm{B} 7$, and $\mathrm{B} 8$. The findings show:

1. Lecturers graduated from overseas universities (LN, the Indonesian term) acquire more in-depth understanding of the subject matter than those graduated from local universities (DN, in the Indonesian term).

2. Lecturers graduated from overseas universities are better able to teach well than those graduated from local universities.

3. In teaching methods, lecturers graduated from local universities are better than those graduated from overseas universities.

4. Attitudes of lecturers graduated from overseas universities are better than those graduated from local universities.

5. Lecturers graduated from overseas universities are more disciplined than those graduated from local universities.

6. Lecturers graduated from overseas universities are more articulate in teaching rather than their counterpart

7. In the use of teaching media, lecturers graduated from local universities are more qualified than those graduated from overseas universities.

8. In improving students' comprehension of the lesson, lecturers graduated from overseas universities can do better than those graduated from local universities

The following graph recapitulates the findings on this issue: 


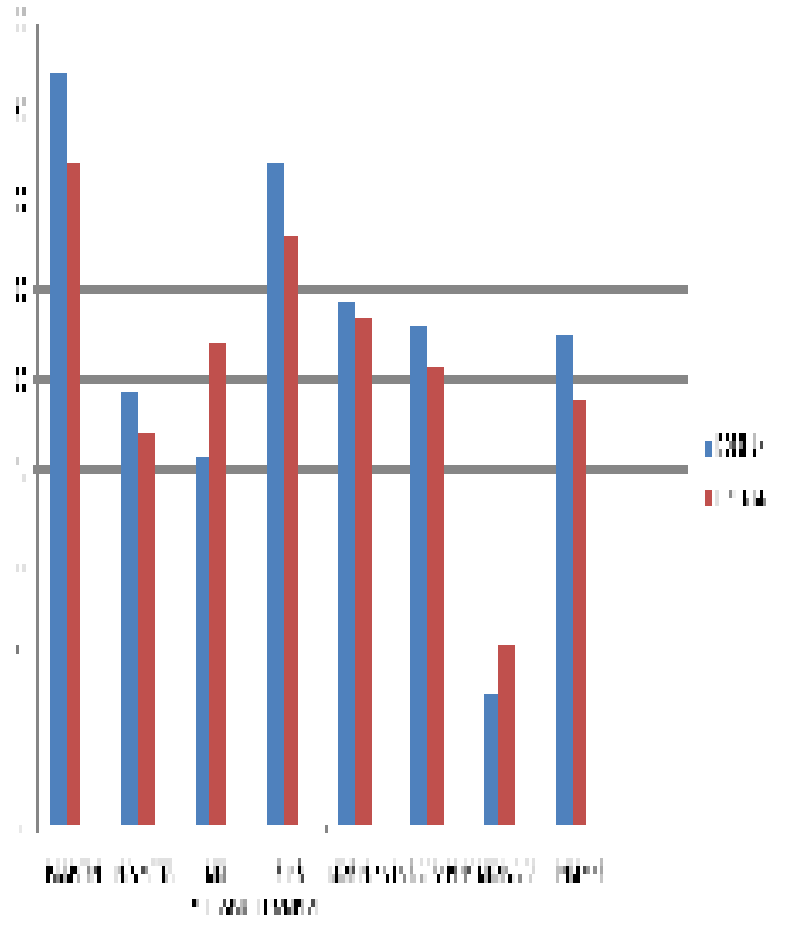

Graph 1. Lecturers' professionalism based on educational background

The above table shows that there is no significant difference in the eight components between lecturers graduated from overseas universities and those who graduate from local universities. For example, the table shows there is no significant difference in the mastery of subject matter between lecturers graduated from overseas universities $(80 \%)$ and those graduated from local universities $(74 \%)$. The same is true with the technique in delivering subject matter or in pedagogical content knowledge, both types of lecturers do not show any significant difference, which is $49 \%$ for the graduates of overseas universities and $44 \%$ for their counterparts. In terms of the instructional methodologies, the research also found common thread, in which $43 \%$ for the graduate of overseas universities and $54 \%$ for those graduated from local universities. Similar phenomenon is also found only slightly differences in lecturer attitude, in which the former were perceived $74 \%$ and the latter was $66 \%$. Discipline and the clarity of assessment procedure are also found to be similar between the two types of lecturers. The lowest grade given by students was in terms of media usage between the two types of lecturers, $15 \%$ for overseas graduates and $20 \%$ for the graduates of the local universities, and the same is true to the last component, which is boosting students' comprehension, in which the students gave 55\% for the overseas graduates and $48 \%$ for their colleagues who graduated from local universities.

\section{Lecturer professionalism based on the level of education}

The findings on this issue show that:

1. Senior lecturers are better able to acquire subject matter than the junior lecturers.

2. Senior lecturers are also better in transferring knowledge compared to their counterparts.

3. In terms I teaching methods, junior lecturers are better than the senior lecturers.

4. Junior lecturers are better in terms of appearance compared to their senior.

5. Junior lecturers are found to be more disciplined than their senior.

6. In the clarity of transferring knowledge, the senior is better able than their juniors.

7. Junior lecturers are more qualified in using media than their seniors.

8. In boosting students' comprehension, senior lecturers do better than their juniors.

Below recapitulates the findings:

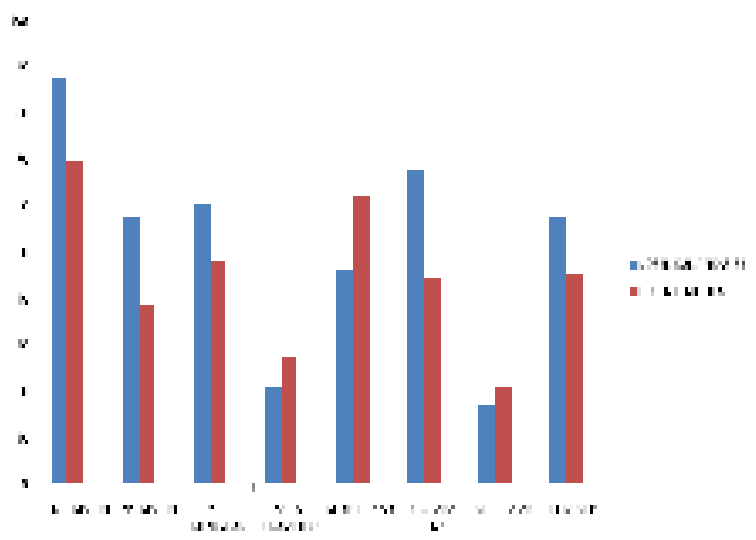

Graph 2. Lecturer professionalism based on the level of education 
The diagram shows that degree does influence the level of subject matter mastery. Students see that lecturers holding doctorate degree are better able to understand the subject they are teaching (88\%) compared to those holding masters' degree (70\%). Likewise, lecturers holding doctorate degree teach better than those holding master degree. Students perceive lecturers with doctorate degree $(58 \%)$, while those with the master degree were seen (39\%).

In terms of teaching methods, lecturers holding the doctorate degree were seen as better $(60 \%)$ and their counterparts holding master degree $48 \%$. Sixty two percents students participating in the study perceive lecturers holding master's degree are more disciplined than those holding doctorate's degree in which $46 \%$ students perceive as such.

In addition, the data on the clarity of assessment procedure shows significant different between those with doctorate's degree and lectures with masters' degree by almost 2 percent. Sixty eigth percents of students perceive lecturers with doctorate's degree give clearer information on assessment procedure than those with master's degree (44\%).

While lecturer's holding doctorate degree was seen as better than those with the master's degree in many respects, in terms of media usage, the formers were $17 \%$, while the latter were $21 \%$. In addition, in terms of boosting students' comprehension, students see that lecturers holding doctorate degree are better able to improve students' comprehension for about 10 percent. Lecturers holding doctorate's degree were $58 \%$, while those holding master's degree were $45 \%$.

\section{Teaching professionalism of lecturers based on age}

Based on students' evaluation of lecturers' professionalism seen from age differences, it is shown that:

1. Senior lecturers acquired better knowledge on subject matter than the junior ones

2. In terms of transferring knowledge, senior teachers are more qualified than the junior one.
3. The finding shows that junior teachers teach better than do senior lecturers.

4. Junior teachers are better in styles and attitudes compared to those of the senior.

5. In terms of discipline, senior lecturers are more disciplined than those of the junior ones.

6. The senior lecturers show more clarity in teaching procedure compare to junior lecturers.

7. In madia usage, the junior are better than are the senior.

8. In boosting students' comprehension, senior lecturers are better than the junior ones.

The following graph shows detailed information on the issue:

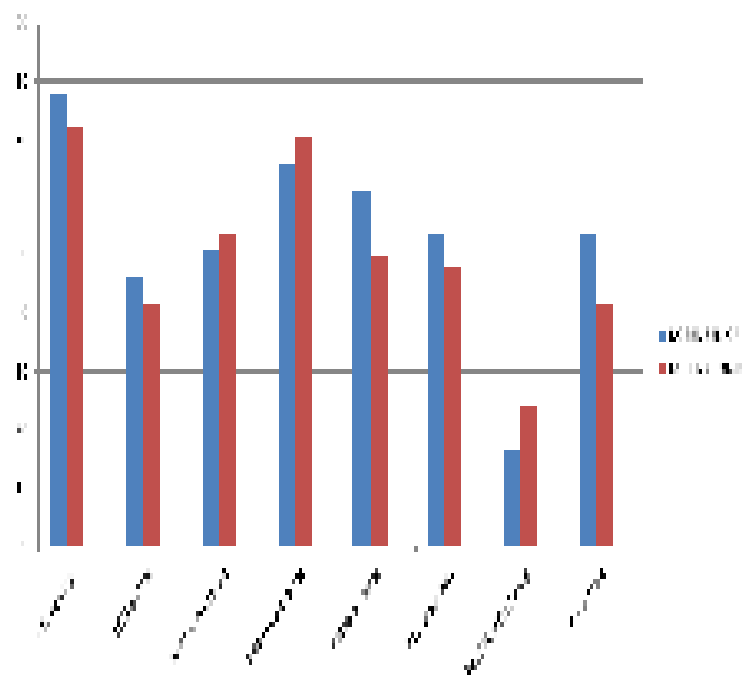

\section{Graph 3. Teaching professionalism of lecturers based on age}

The graph shows that there is no significant difference in mastering subject matter between the junior and the senior lecturers, in which only $6 \%$ gap between the junior and seniors. Students perceived the former $72 \%$, while the latter is $78 \%$ in their mastery of the subject matter. Likewise, in transferring knowledge, there is no significant difference perceived by students between the senior $(46 \%)$ and the junior ones $(42 \%)$. This similar perception also given to lecturer's teaching methods. Students perceived senior lecturers $51 \%$, in their use of teaching methods, and $54 \%$. 
There is a slightly different between senior and junior lecturers in terms of styles and attitudes. There is only $4 \%$ difference between the two types of lecturers. Students perceive senior lecturers $66 \%$, while their counterparts the junior one is $70 \%$.

In terms of discipline, senior lecturers $(61 \%)$ are perceived as better than the junior one, which is $(50 \%)$. The graph also shows that senior lecturers give clearers information on assessment procedure by $6 \%$.

In regard with the use of teaching media, both senior and junior lecturers were perceived as not very competent. The data, for example show that senior lecturers were only $17 \%$ perceived as capable of using teaching media effectively, while the junior ones were only perceived $24 \%$.

Finally, the graph shows that in terms of the ability to boost students' comprehension, $54 \%$ senior lectures were perceived to be competent in this component, while $42 \%$ junior lecturers were seen as such.

\section{Lecturers' professionalism at department of Arabic education based on gender}

Students' evaluation on lecturers' professionalism based on gender, can be seen in the following analysis:

1. Female lecturers are seen as more capable in subject matter mastery, compared to male lecturers.

2. In delivering teaching materials, female lecturers were also seen as more competent than their counterparts.

3. Likewise, in terms of teaching methodology, female lecturers were seen to be more creative than the male lecturers.

4. In terms of style and attitude female lecturers were seen as better than the male lecturers.

5. Female lecturers are more disciplined than are the male lecturers.

6. In terms of clarity in teaching process, female are perceived as better than the male ones.

7. In the use of learning media, female lectures are better than the male ones.
8. In terms of boosting students' comprehension, female lecturers $(74 \%)$ are better than male lecturers.

It can be seen in the following graph:

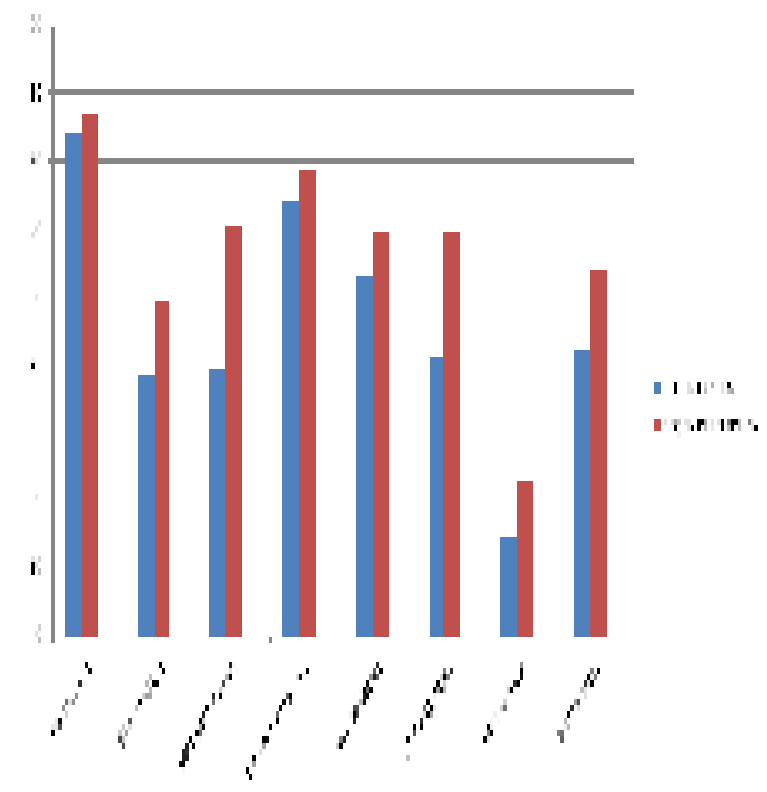

\section{Graph 4. Lecturers' professionalism at department of Arabic education based on gender}

Based on the above graph, there is no significant different between respondents' gender with material achievement. It can be shown that the average score of female lecturer in mastering material is $77 \%$ as perceived by the students.

There is no significant difference between the female and male lecturers. Students perceive female lecturers $(49 \%)$ are better in delivering teaching materials than the male lecturers $(38 \%)$. In the other elements, the graph shows that female lecturers are better in their teaching methodology by almost $30 \%$ difference between the two groups; female $60 \%$, while male $39 \%$. Although in teaching methodology the gap is rather big, in terms of styles and attitude and also in terms of discipline, female lecturers score high $59 \%$ compare to $53 \%$ of male lecturers.

In addition, female lecturers were perceived as better able in providing clarity in 
the assessment system. The graph shows that $59 \%$ percent female lecturers were clearer in their assessment procedure compare to $41 \%$ of male lecturers. The findings of the study show that the lowest score was in term of media usage. Only $23 \%$ female lecturers were perceived by students in terms of their use of media, while $14 \%$ of male lecturers were perceived as so. Students also perceived that $54 \%$ female lecturers are able to improve students' understanding, while $42 \%$ were seen as male lecturers.

This article has examined teaching professionalism of Arabic department lecturers of IAIN Imam Bonjol Padang. The variables used in the research are educational backgrounds; level of education; age; and gender.

\section{Lecturers' professionalism as viewed from background of education}

Lecturers participating in this study were categorized into two groups based on their educational background; overseas and local graduates. Two lecturers A1 and B2 graduated from overseas universities, while 11 of them A2, A3, A4, A5, B1, B3, B4, B5, B6, B7 and B8. Lecturers' professionalism is viewed based on their ability in material mastery; techniques in teaching materials; disciplined; attitudes and performance; instructional methods; clarity in assessment; the use of instructional media; and boosting of students' understanding.

The data from 42 items in questionnaire yield several important results:

1. Lecturers graduated from overseas universities (LN, the Indonesian term) acquire more in-depth understanding of the subject matter than those graduated from local universities (DN, in the Indonesian term).

2. Lecturers graduated from overseas universities are better able to teach well than those graduated from local universities.

3. In teaching methods, lecturers graduated from local universities are better than those graduated from overseas universities.
4. Attitudes of lecturers graduated from overseas universities are better than those graduated from local universities.

5. Lecturers graduated from overseas universities are more disciplined than those graduated from local universities.

6. Lecturers graduated from overseas universities are more articulate in teaching rather than their counterpart

7. In the use of teaching media, lecturers graduated from local universities are more qualified than those graduated from overseas universities.

8. In improving students' comprehension of the lesson, lecturers graduated from overseas universities can do better than those graduated from local universities

Lecturers' professionalism as viewed by the level of education

Based on the data from questionnaires, it is found that

1. Senior lecturers, those with the doctorate degree are better able to acquire subject matter than the junior lecturers, those with master degree.

2. Senior lecturers are also better in transferring knowledge compared to their counterparts.

3. In terms of teaching methods, junior lecturers (Master degree) are better than the senior lecturers (Doctorate degree).

4. Junior lecturers (Master degree) are better in terms of appearance compared to their seniors (Doctorate degree).

5. Junior lecturers (Master degree) are found to be more disciplined than their seniors (Doctorate degree).

6. In the clarity of transferring knowledge, the seniors (Doctorate degree) are better able than their juniors (Master degree).

7. Junior lecturers (Master degree) are more qualified in using media than their seniors (Doctorate degree).

8. In boosting students' comprehension, senior lecturers (Doctorate degree) do better than their juniors (Master degree).

\section{Lecturers' professionalism as viewed by age differences}

1. Senior lecturers acquired better knowledge on subject matter than the junior ones 
2. In terms of transferring knowledge, senior teachers are more qualified than the junior one.

3. The finding shows that junior teachers teach better than do senior lecturers.

4. Junior teachers are better in styles and attitudes compared to those of the senior.

5. In terms of discipline, senior lecturers are more disciplined than those of the junior ones.

6. The senior lecturers show more clarity in teaching procedure compare to junior lecturers.

7. In madia usage, the junior are better than are the senior.

8. In boosting students' comprehension, senior lecturers are better than the junior ones.

Lecturers' professionalism as viewed by gender

1. Female lecturers are seen as more capable in subject matter mastery, compared to male lecturers.

2. In delivering teaching materials, female lecturers were also seen as more competent than their counterparts.

3. Likewise, in terms of teaching methodology, female lecturers were seen to be more creative than the male lecturers.

4. In terms of style and attitude female lecturers were seen as better than the male lecturers.

5. Female lecturers are more disciplined than are the male lecturers.

6. In terms of clarity in teaching process, female are perceived as better than the male ones.

7. In the use of learning media, female lectures are better than the nake ones.

8. In terms of boosting students' comprehension, female lecturers $(74 \%)$ are better than male lecturers.

\section{CONCLUSION}

The research explores how students of Arabic department perceive their lecturers' professionalism based on certain variables: lecturers' educational backgrounds, level of education, age, and lecturers' gender. If lecturers are competent in their teaching, it is assumed that instructional process will also improve. Competent teachers will also help improve educational quality; instructional process, evaluation of lecturers' professionalism. The findings indicate that generally $50 \%$ students perceive lecturers' professionalism as satisfactory. The findings are generated through interviewing lecturers by examining their ways of transferring the lessons, teaching methods, styles and attitudes, media usage and the ability to increase students' understanding.

There are also no significant differences between those who graduate from local and overseas universities. However, level of education is proven to be significantly differences in the level of professionalism, especially in the mastery of materials, technique of transferring materials, teaching methodology, styles and attitudes, clarity in assessment procedure, and the ability to boost students' comprehension. Female lecturers' outperform male lecturers in some respects.

\section{REFERENCES}

Adi W. Gunawan. (2003). Born To Be A Genius, Jakarta: Gramedia Pustaka Utama.

Adi W. Gunawan. (2005). Hypnosis: The Art of Subconscious Communication, Jakarta: Gramedia Pustaka Utama.

Adi W. Gunawan. (2006). Hypnotherapy: The Art of Subconscious Restructuring, Jakarta: Gramedia Pustaka Utama.

Adi W. Gunawan. (2007). The Secret of Mindset, Jakarta: Gramedia Pustaka Utama.

Adi W. Gunawan. (2009). Quantum Life Transformation, Jakarta: Gramedia Pustaka Utama.

Afnibar. (2005). Memahami Profesi dan Kinerja Guru, Jakarta: The Minangkabau Foundation.

Budiningsih, A. (2012). Belajar dan Pembelajaran, Jakarta: Rineka Cipta. 
Covey, S. R. (2010). The 7 Habits of Highly Effective People, ed. Lyndon Saputra, Jakarta: Binarupa Aksara.

Danim, S. (2012). Profesionalisasi dan Etika Profesi Guru, Bandung: Alfabeta.

Depdikbud. (1989). Kamus Besar Bahasa Indonesia, Jakarta: Balai Pustaka, 1989.

Elfiky, I. (2010). Jangan Tunda untuk Sejahtera, terj. Banani Bahrul Hassan dan M. Taufik Damas, Jakarta: Zaman.

Elfiky, I. (2010). Terapi Positive Thinking, Mengontrol Otak untuk Sehat Jiwa Raga, terj. Abu Firly Bassam Taqiy, Yogyakarta: Hikam Pustaka.

Elfiky, I. (2011). Personal Pzower, terj. Aisyah, Jakarta: Zaman.

Elfindri et. al. (2010). Soft Skills untuk Pendidik, t.k.: Baduose Media.

Fox, A. (2009). Mengendalikan Konflik, terj. Ary Kristanti, Surabaya: Selasar Surabaya Publishing.

Hanafi, Hasan, Al-Mu'ashir, F. F. (1983). Beirut: Dar al-Tanwir.

Jamal, A. (2009). Jangan Tunda untuk Bahagia, terj. Desi Sari Puspita dan Dedi Slamet Riyadi, Jakarta: Zaman.

Mahmud, Sayyid, Y. Tathwir al-Ta'lim alJami'iy. (2009). Cairo: Dar al-Kitab alMasry al-Lubnaniy, cet. I

Mar'at. (1999). Sikap Manusia Perubahan Serta Pengukuranya, (Jakarta: Ghalia Indonesia.

Marzuki. (1990). Metodologi Penelitian Riset, Jakarta: BPEP.

McNamara, G, \& O'Hara, J. (2009). Trusting Schools and Teachers: Developing Educational Professionalism through Self-evaluation. New York: Peter Lang.

Miarso, Yusufhadi, "Pengembangan Profesionalisme Dosen Dalam Rangka Peningkatan Mutu Perguruan Tinggi", dalam http://yusufhadi.net.
Miller, D. (2008). Tim Juara, terj. Dicky Satyadewa, Jakarta: Erlangga.

Mudlofir, A. (2012). Pendidik Profesional, Jakarta: Raja Grafindo Persada.

Mulyana, D. (2005). Ilmu Komunikasi: Suatu Pengantar, Bandung: Remaja Rosdakarya.

Muqowim. (2012). Pengembangan Soft Skill Guru, Yogyakarta: Pedagogia.

Nurdin, S. (1999). Guru Profesional Dan Implementasi Kurikulum, Padang: IAIN Press, cet. ke-1

Raja, O. et. Al. (2010). 101 Motivator yang Menginspirasi Dunia, Jakarta: L Press.

Rakhmat, J. (1994). Psikologi Komunikasi, Bandung: Remaja Rosdakarya.

Rangkuti, F. (2006). "Measuring Customer Satisfaction: Gaining Customer Relationship Strategy", Jakarta, Gramedia Pustaka Utama.

Redaksi Sinar Grafika, UU Sisdiknas 2003, (UU RI No. 20 Th. 2003), Jakarta: Sinar Grafika, 2005, cet. ke-2

Saleh, Rahman, A. (2003). Madrasah dan Pendidikan Anak Bangsa Visi, Misi dan Aksi, Jakarta: PT Raja Grafinso Persada.

Sapuri, R. (2009). Psikologi Islam; Tuntunan Jiwa Manusia Modern, Jakarta: Rajawali Pers.

Sedarmayanti. (1994). Sumber Daya Manusia dan Produktivitas Kerja, Bandung, Ilham Jaya.

Shaleh, Rahman, A. \& Wahab, M. A. (2005). Psikologi Suatu Pengantar dalam Perspektif Islam, Jakarta: Kencana, cet. ke-2

Sobur, A. (2003). Psikologi Umum, (Bandung: Pustaka Setia, hal. 445.

Sudarman, D. (2002). Inovasi Pendidikan Dalam Upaya Peningkatan Profesionalisme Tenaga Kependidikan, Jakarta: Pustaka setia, cet. ke-1. 
Sudjono, A. (1997). Pengantar Sratistik Pendidikan, Jakarta: CV Raja Gratindo Persada.

Sugiyono. (2008). Metode Penelitian Pendidikan; Pendekatan Kuantitatif, Kualitatif, dan $R \& D$, Jakarta: Alfabeta.

Syam, N. "Standardisasi Dosen Perguruan Tinggi", dalam http://nursyam.sunanampel.ac.id

Tillman, D. \& Colomina, P. Q. (2007). LVEP Educator Training Guide, terj. M. Ika Purwowigati, Jakarta: Grasindo.

Tillman, D. (2004). Living Values Activities for Young Adults, terj. Risa Praptono dan Ellen Sirait, Jakarta: Grasindo.

Tolkhah, I. \& Barizi, A. (2004). Membuka Jendela Pendidikan Menjadi Akar Tradisi dan Integrasi Keilmuan Pendidikan Islam, Jakarta: PT Raja Grafindo Persada.

Wirawan, S. (1983). Teori-teori Psikologi Sosial, Jakarta: Grafindo.

Zain, Romli, Sy. Strategi Pengembangan Profesionalisme Dosen Di Indonesia (Sebuah Sumbang Saran); in www.atdikcairo.org 